\title{
Museu Virtual do Corpo Humano: Ambiente Virtual de Aprendizagem para o Ensino de Ciências Morfológicas
}

\author{
Tatiana Montanari \\ Departamento de Ciências Morfológicas, ICBS, UFRGS, t.montanari@bol.com.br \\ Eliane de Oliveira Borges \\ Departamento de Fisiologia, ICBS, UFRGS, elianeoborges@ig.com.br
}

Resumo: Um ambiente virtual de aprendizagem foi desenvolvido para apoiar o ensino de Biologia celular, Histologia e Embriologia, disciplinas da área das Ciências Morfológicas. O recurso educacional consiste em um museu virtual, que reúne o acervo de imagens obtidas em microscopia de luz e eletrônica, utilizadas nessas disciplinas. Além desse material, foram confeccionadas animações para ilustrar as características anatômicas e fisiológicas dos sistemas do corpo humano. As imagens e as animações são apresentadas na forma de vídeos acompanhados de narração. O internauta dispõe de três ambientes de visitação: Conhecendo a célula, Conhecendo o corpo humano e $\mathrm{O}$ Surgimento da vida. O Museu virtual do corpo humano foi disponibilizado no endereço www.ufrgs.br/museuvirtual.

Palavras-chave: ambiente virtual de aprendizagem; corpo humano; célula; histologia; embriologia.

\section{Museu virtual do corpo humano: a virtual learning environment for teaching of Morphological Sciences}

Abstract: A virtual learning environment was developed to support the teaching of Cell Biology, Histology and Embryology, subjects from Morphological Sciences. The educational resource consists of a virtual museum, which contains collection of pictures obtained for light and electron microscopy, used in these subjects. Besides of this material, animations were made for illustrating the anatomical and physiological characteristics from human body's systems. The photographs and animations are exhibited as video with narration. The Internet user has three rooms for visitation: Knowing the cell, Knowing the human body and Emergence of life. The Museu virtual do corpo humano is available at www.ufrgs.br/museuvirtual.

Keywords: virtual learning environment; human body; cell; histology; embryology.

Sessão do artigo: Ambientes virtuais de aprendizagem

\section{INTRODUÇÃO}

O avanço tecnológico na área de comunicação, com o desenvolvimento da internet, teve forte impacto nas relações sociais e na educação. A interatividade, as diferentes linguagens usadas (escrita, sonora e visual) e a possibilidade de visualização em representações tridimensionais e animações contribuem para o processo de ensino e aprendizagem. Além disso, a internet permite a aprendizagem autônoma pelo aluno, independente do ambiente institucional de ensino e de horários rígidos e préestabelecidos, o que a torna uma ferramenta de democratização do saber. 
É oportuno aproveitar os recursos das novas tecnologias educacionais para divulgar o conhecimento e fomentar o ensino de disciplinas tradicionais, como as das Ciências Morfológicas: Biologia celular, Histologia e Embriologia. A Biologia Celular estuda a célula (a menor unidade estrutural e funcional do ser vivo) e os seus constituintes, e a Histologia estuda os tecidos e os sistemas do organismo numa abordagem em nível microscópico (Montanari, 2012a). A Embriologia trata do desenvolvimento do ser, desde a formação dos gametas até o nascimento (Montanari, 2012b).

Assim, pretendeu-se desenvolver um ambiente virtual de aprendizagem sob a forma de um Museu virtual, que reunisse o acervo de imagens obtidas em microscopia de luz e eletrônica, utilizadas nessas disciplinas.

A concepção pedagógica do projeto foi fundamentada nos estudos epistemológicos de Piaget $(1976 ; 1998)$, em que constatou que o conhecimento é construído na interação do sujeito com o objeto. “(...) os conhecimentos derivam da ação (...). Conhecer um objeto é agir sobre ele e transformá-lo, apreendendo os mecanismos dessa transformação vinculados com as ações transformadoras" (Piaget, 1976, p. 37). "(...) toda a assimilação é uma reestruturação ou reinvenção" (Piaget, 1976, p. 48).

Nas suas considerações sobre o ensino, Piaget já mencionava a dificuldade que o professor experimenta em se fazer compreender pelos alunos quando o verbalismo é concebido como o principal instrumento educacional. Ressaltava a importância do trabalho pessoal no processo de aprendizagem (Piaget, 1998, p. 138-139). "O que permanece é o conjunto do saber fundado numa atividade real, ou seja, na iniciativa pessoal, num esforço sistemático de assimilação, nos verdadeiros interesses (o interesse sendo, conforme a profunda concepção de J. Dewey, a participação de toda a personalidade no trabalho proposto). O que desaparece, ao contrário, é o que foi simplesmente recebido de fora, o que foi gravado ou memorizado sem um móbil ativo, sem outro interesse que aquele, totalmente extrínseco, de se submeter aos usos e costumes escolares ou de passar o exame" (Piaget, 1998, p. 149).

Em "Escolas que aprendem", os autores também apontam a importância da ação no processo de aprendizagem: "As pessoas aprendem em ciclos, movendo-se naturalmente entre a ação e a reflexão, entre a atividade e o repouso" (Senge et al., 2005, p. 66).

Investigações sobre a aprendizagem mostraram que a percepção visual é o sentido mais desenvolvido em humanos e é uma importante maneira pela qual aprendemos. A visão permite-nos coletar e processar informações de nosso ambiente e tomar decisões ou formar conceitos sobre essa informação. A visualização auxilia a compreensão de processos complexos, porque ela permite a conversão de um conceito abstrato para um objeto visual específico que pode ser mentalmente manipulado. A retenção do conteúdo como memória de longo prazo é facilitada por uma combinação de estímulos verbais e visuais, como, por exemplo, animações acopladas a uma narração. Também é favorecida quando o conteúdo é apresentado como filmes ou vídeos, ao invés, de imagens estáticas (McClean et al., 2005).

Nas disciplinas das Ciências Morfológicas, a informação visual é de suma importância. A maior parte do conhecimento adquirido nessa área foi obtida através da observação, ao microscópio de luz e ao microscópio eletrônico, de células isoladas ou 
em cortes de tecidos ou órgãos. Não há como dissociar o conteúdo teórico das imagens obtidas nesses equipamentos, e as habilidades de reconhecimento e classificação são fundamentais para a compreensão.

Estudos mostram a eficácia da linguagem visual e das atividades multimídia, em especial de animações combinadas com narração, na aprendizagem (Mayer \& Gallini, 1990; Heyden, 2004; Stith, 2004; McClean et al., 2005). As atividades multimídias, resultantes da combinação de texto, imagens, vídeo, som e animação, permitem ainda a repetição, estimulam a exploração pelo estudante, favorecem a compreensão de processos visuais complexos e acomodam-se aos vários estilos de aprendizagem (Heyden, 2004).

A partir desses pressupostos, a interatividade e a linguagem multimídia foram consideradas como pontos de referência para desenvolver o recurso digital, decidindo-se utilizar, como principal recurso de apresentação do conteúdo, vídeos ilustrados com animações, acompanhados de narração explicativa.

Além do acervo permanente, pretendia-se que o Museu virtual tivesse uma exposição temática, oportunizando a divulgação de trabalhos na área morfológica ou clínica, aproximando o saber científico da comunidade acadêmica e do público em geral.

\section{OBJETIVOS}

A criação do Museu virtual do corpo humano visa:

- difundir o conhecimento das Ciências Morfológicas, que incluem as disciplinas de Biologia Celular, Histologia e Embriologia;

- fomentar o conhecimento dos componentes do corpo humano - os sistemas, os tecidos e as células - utilizando recursos visuais e interativos construídos a partir de fotografias obtidas ao microscópio de luz e ao microscópio eletrônico e de animações;

- propiciar de forma dinâmica a compreensão do desenvolvimento do indivíduo, desde a produção dos gametas e do seu encontro no processo de fertilização até o período embrionário e fetal.

\section{METODOLOGIA}

A interatividade e a apresentação do conteúdo em linguagem visual, potencializada por atividades multimídias foram consideradas referenciais para construir a navegação e o design do ambiente virtual de aprendizagem.

Visando oferecer navegação hipertextual amigável e interativa, o software de montagem foi o Adobe Dreamweaver. Ele permitiu a criação rápida e eficiente de modelos de design em linguagem $H T M L$, dos quais o escolhido foi aquele que apresentava como características: ser intuitivo, de fácil navegação e objetivo. Os autores optaram pelo predomínio da cor branca como fundo de tela, porque, além de salientar tipos gráficos e imagens, estimula os sentidos, trazendo a sensação de clareza. Os ícones criados procuraram sintetizar o conteúdo abordado.

Os vídeos foram realizados com a associação de fotografias, animações e áudio. As fotografias são de peças macroscópicas ou de cortes histológicos dos diferentes V. $10 \mathrm{~N}^{\mathrm{o}} 3$, dezembro, 2012 
órgãos que integram os sistemas representados. Além de fotomicrografias (obtidas ao microscópio de luz), foram utilizadas eletromicrografias (obtidas ao microscópio eletrônico). Esse material é proveniente de trabalhos de pesquisa ou do acervo da disciplina. A maioria das fotos utilizadas nos filmes possui alta resolução. Essas imagens foram ordenadas de acordo com o roteiro e sinalizadas por setas ou legendas.

As ilustrações das animações foram elaboradas com o software Adobe Illustrator a partir de imagens selecionadas da literatura científica. Na sua concepção, procurou-se evidenciar a forma das estruturas anatômicas, diferenciando-as pelas cores e ressaltando aquelas abordadas durante a animação através da ocultação das cores das demais. $\mathrm{O}$ cenário de fundo utilizado para as ilustrações animadas foi o plano azul escuro, liso, sem textura, compondo uma imagem serena e agradável.

A montagem das animações e das fotografias foi realizada com o software Adobe After effects de acordo com o roteiro escrito sobre o conteúdo. Na sua redação, procurou-se evidenciar as atividades consideradas importantes para o entendimento do funcionamento dos sistemas abordados. Além da sequência das imagens, a fala para cada imagem e as estruturas a serem sinalizadas ou legendadas foram marcadas no roteiro. Na gravação do áudio, foi utilizada voz feminina e pausada. A partir dos arquivos de som, seguiu-se a montagem do filme. Após a sua edição, os filmes foram exportados com a extensão FLV.

No programa Adobe Dreamweaver, as páginas HTML foram criadas e os filmes adicionados. A navegação permite várias ações, como pausar, retroceder ou avançar a exibição do vídeo, regular o volume do áudio, retornar à página inicial ou acessar outra seção sem retornar à homepage. Para a publicação do ambiente virtual de aprendizagem, seguiu-se o protocolo para hospedagem de websites do Centro de Processamento de Dados (CPD) da instituição.

\section{RESULTADOS E DISCUSSÃO}

O Museu virtual do corpo humano (disponível em www.ufrgs.br/museuvirtual) é uma proposta de ambiente virtual para o ensino e a aprendizagem de disciplinas de Ciências Morfológicas: Biologia celular, Histologia e Embriologia.

Baseando o seu planejamento nas teorias piagetianas de que o conhecimento é construído na interação do sujeito com o objeto (Piaget, 1976; 1998), a iniciativa pessoal e a interatividade foram referenciais para desenvolver o recurso digital. Assim, foi utilizado o software Adobe Dreamweaver para obter uma navegação hipertextual amigável e interativa, onde o internauta terá possibilidade de ser sujeito no processo de ensino ao interagir com o acervo do Museu, fazendo escolhas sobre o que deseja conhecer, selecionando opções e ativando animações/vídeos.

Nessa interação com os elementos do Museu, espera-se que o visitante se familiarize com conceitos típicos da área morfológica; estruture de forma correta $o$ pensamento sobre o todo e as partes no que se refere à organização do corpo humano e compreenda o desenvolvimento humano.

Esse conteúdo foi dividido em três seções apresentadas na página inicial: Conhecendo a célula, Conhecendo o corpo humano e $\mathrm{O}$ surgimento da vida. $\mathrm{O}$ tópico Conhecendo a célula foi ilustrado com uma eletromicrografia de macrófago, que, pela sua atividade funcional, exibe riqueza em organelas. $\mathrm{O}$ tópico Conhecendo o corpo 
humano foi ilustrado com o desenho do contorno do corpo com os órgãos dos sistemas respiratório e digestório posicionados. $\mathrm{O}$ tópico $\mathrm{O}$ surgimento da vida foi ilustrado com uma foto macroscópica de um feto. Ainda há, na página principal, o link para acessar as apresentações do evento temático (Figura 1).

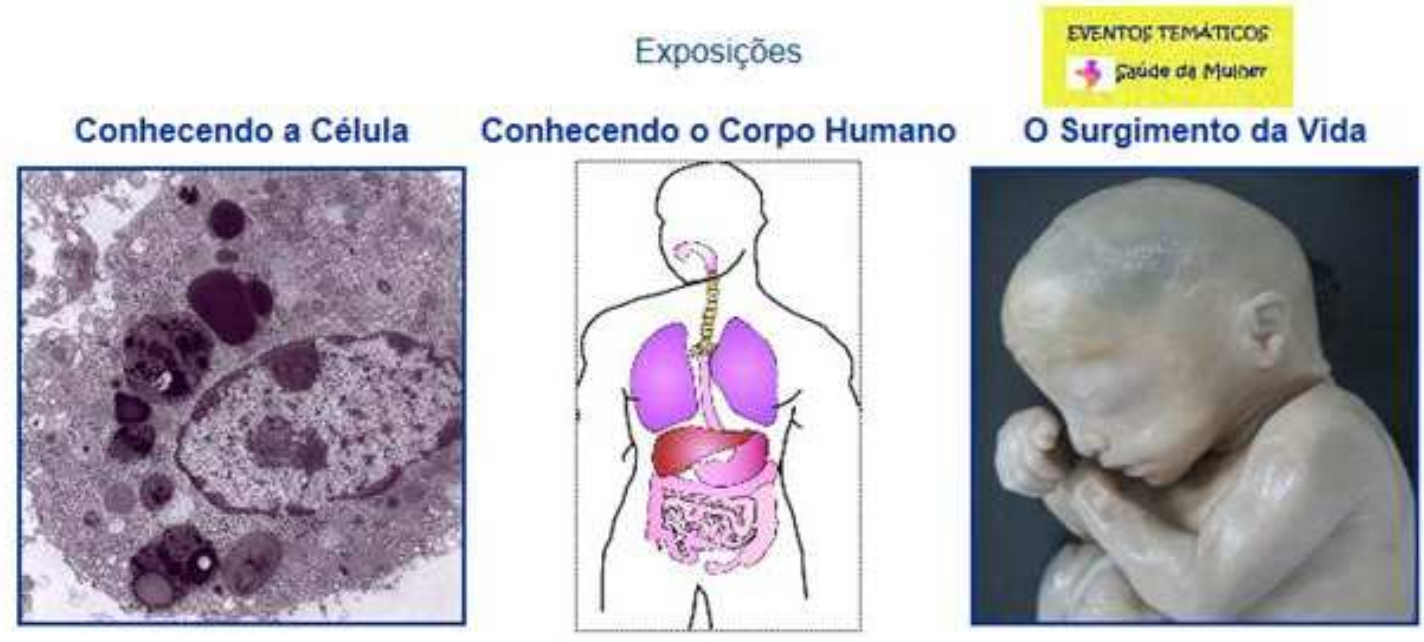

Figura 1 - Homepage do ambiente virtual.

O internauta, ao clicar na imagem que ilustra o tópico Conhecendo a célula, entra na página que contém um vídeo com 5'30" de duração, abordando os diversos tipos celulares, sua morfologia, função e localização. Além de fotomicrografias exibindo as células de diferentes tecidos e órgãos, são apresentadas eletromicrografias das organelas para explicar a constituição da célula (Figura 2). As imagens foram organizadas de acordo com o roteiro, e o único tratamento que sofreram foi em relação ao tamanho, já que algumas eram maiores que as dimensões do fundo. Setas animadas foram acrescentadas para indicar os constituintes.
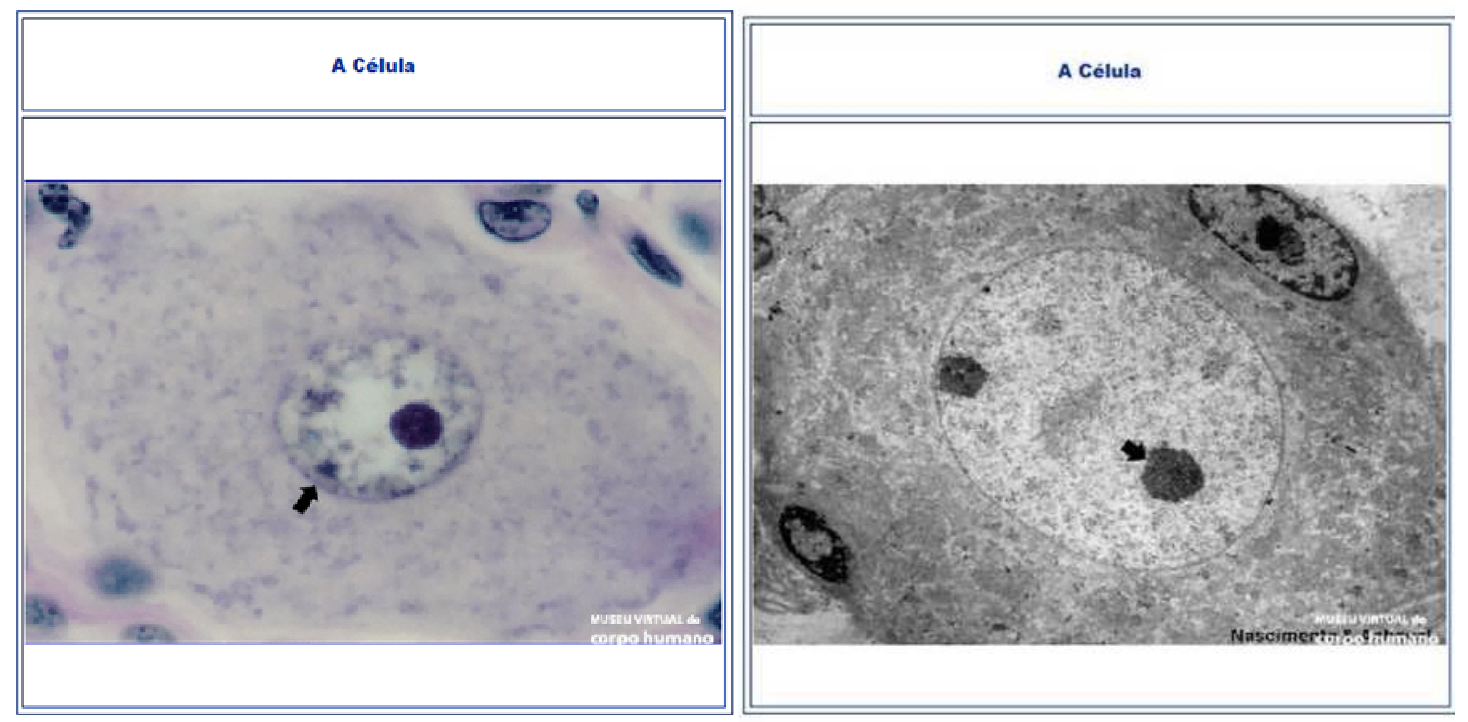

Figura 2 - Fotomicrografia e eletromicrografia de neurônio pseudounipolar exibidas no vídeo Conhecendo a célula. 
Ao clicar sobre a figura do tópico Conhecendo o corpo humano, o visitante acessa o acervo de filmes sobre Sistema Respiratório, Sistema Digestório e Sistema Urinário (Figura 3). Os vídeos foram confeccionados com animações, fotomicrografias e eletromicrografias dos órgãos desses sistemas, sendo abordadas as características anatômicas e histológicas desses sistemas, a sua atividade funcional e a sua importância no organismo (Figura 4).

\section{Exposiçóes $>$ Conhecendo a Célula $>$ Conhecendo o Corpo Humano $>0$ Surgimento da Vida}

Acervo - Filmes

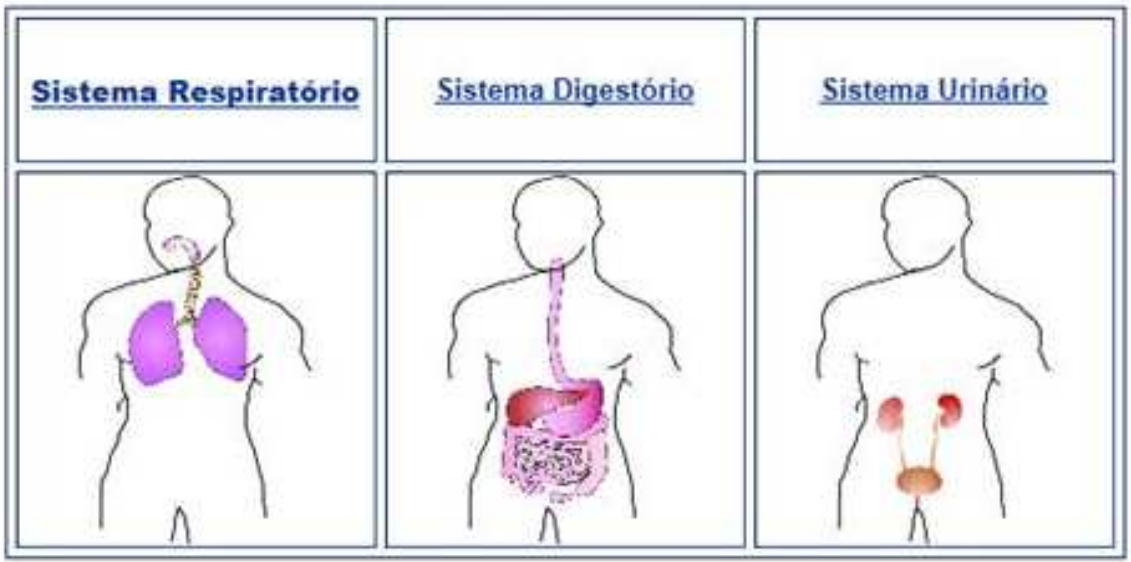

Figura 3 - Tela de navegação da seção Conhecendo o corpo humano.
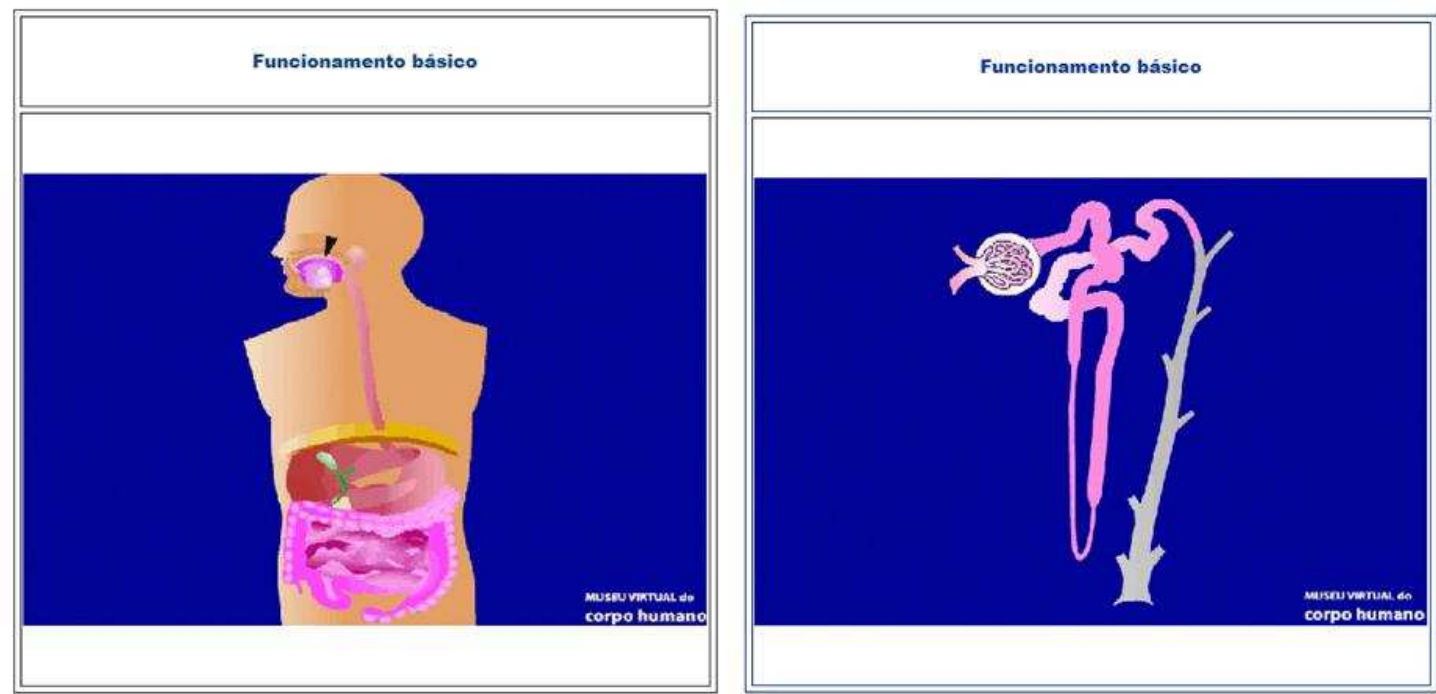

Figura 4 - Ilustrações dos vídeos da seção Conhecendo o corpo humano, elaboradas com o software Adobe Illustrator. A primeira imagem exibe o sistema digestório posicionado no corpo, sendo indicada pela seta a cavidade oral, onde inicia a degradação do alimento. A segunda imagem é o desenho da unidade do rim, onde a urina é formada, sendo destacado em cor o néfron, abordado na narração explicativa. Notar o plano azul escuro do cenário de fundo. 
Ao clicar em O surgimento da vida, inicia vídeo narrado com 3'45" de duração, onde o desenvolvimento do ser humano é sucintamente descrito desde a produção e a fertilização dos gametas até o período embrionário e fetal. Para ilustrar a gametogênese, foram usadas fotomicrografias e eletromicrografias do testículo, mostrando a formação dos espermatozoides, e fotomicrografias do ovário, exibindo o gameta feminino em crescimento. Fotografias de cortes histológicos do sistema reprodutor foram usadas para explicar o transporte dos gametas e o processo de fertilização. Fotografias de embriões de camundongo descrevem o início do desenvolvimento, e imagens de embriões e de fetos humanos e de outros animais serviram para explicar o estabelecimento dos folhetos embrionários e a organogênese (Figura 5). Esse filme não requereu a produção de animações. Suas imagens são bastante claras, e o único tratamento realizado foi referente às dimensões. $\mathrm{O}$ vídeo de uma ultrassonografia fetal foi adicionado à seção (Figura 5).
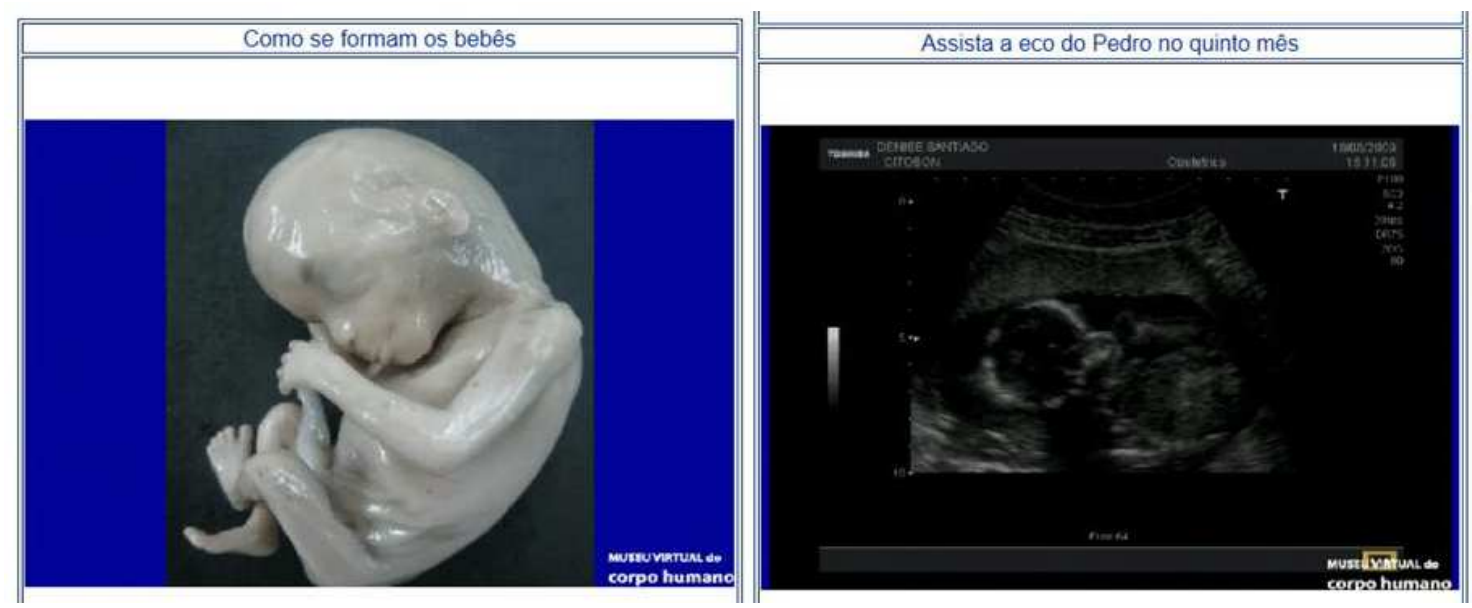

Figura 5 - Fotografia de feto humano do acervo da disciplina, utilizada para ilustrar o conteúdo sobre organogênese, e tela da ultrassonografia, ambas da seção O surgimento da vida.

A informação visual é essencial para a compreensão do conteúdo das Ciências Morfológicas, como já sugerido na própria denominação. Imagens a olho nu ou em microscopia de luz ou eletrônica construíram (e constroem) o conhecimento dessa área. Após o desenvolvimento de um atlas digital (Montanari et al., 2008), constituído por fotografias acompanhadas de legendas, pretendia-se elaborar um recurso educacional onde o conteúdo fosse exibido de forma dinâmica e onde outras linguagens fossem agregadas, por isso a opção por animações e vídeos narrados.

A montagem das fotografias e das animações foi realizada com o software After effects. Nessas produções, coexistem três linguagens paralelas: a linguagem do conteúdo (terminologia científica precisa), a linguagem dos recursos da mídia educacional dinâmica (características de movimento, cor, textura, dimensões etc. relativas às imagens e animações) e a linguagem do próprio software de edição (possibilidades, limitações e exigências dos recursos existentes) (Schnaid et al., 2006).

De acordo com Timm et al. (2003), a partir da conceituação proposta por Costa (1989) e da experiência desenvolvida no Núcleo de Multimídia e Ensino a Distância da Escola de Engenharia da UFRGS, foram utilizados quatro tipos de planos, considerados adequados para a captura de imagens de aulas em vídeo: plano geral (abrange todo o V. $10 \mathrm{~N}^{\mathrm{o}} 3$, dezembro, 2012 
ambiente da cena); plano médio (abrange o objeto, sem isolá-lo do ambiente); plano fechado (foca um detalhe do objeto), e contraplano (um detalhe do que está sendo mostrado por outro ângulo de enquadramento) (Figura 6). Esses planos foram alternados na edição para viabilizar a linguagem dinâmica da narrativa fragmentada.
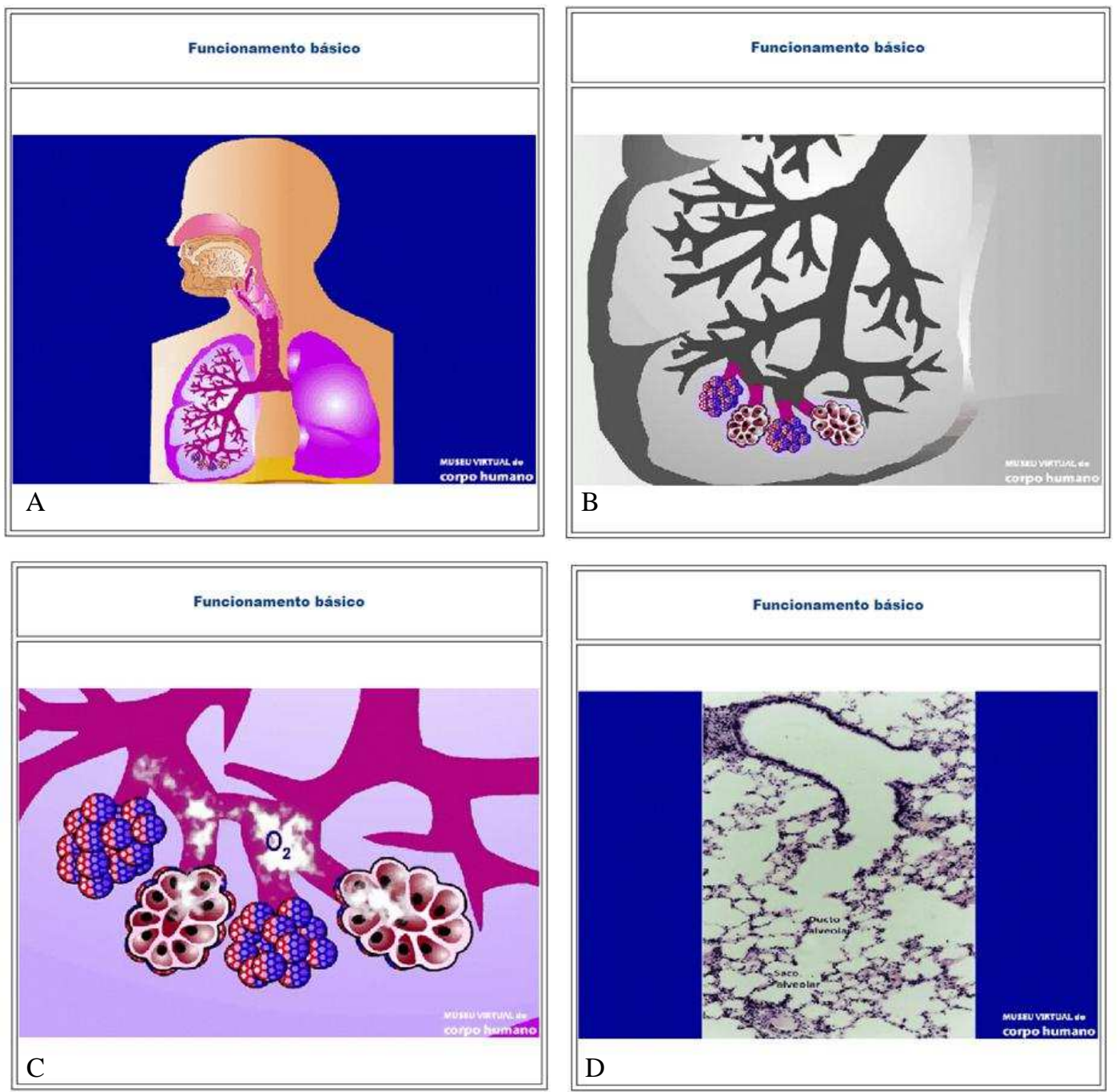

Figura 6 - Telas do vídeo sobre Sistema respiratório, onde é possível observar os planos utilizados: A - geral; B - médio; C - fechado, e D - contraplano (corte histológico).

O padrão das locuções foi o da narratividade, da fluência de forma coloquial, ressalvadas as características do produto educacional de precisão e correção (Timm et al., 2003).

Os conteúdos dos vídeos foram disponibilizados conceitualmente claros, com sequência lógica, de natureza adequada à base teórica de alunos do ensino médio e superior. Como propõem Cabral Júnior et al. (2005), as informações foram colocadas de forma a serem captadas mediante percepção visual estática (imagens, sinalizações), dinâmica (animações gráficas, sinalizações) e percepção auditiva verbal.

Apesar de ser rotineiro nos meios de comunicação de massa o uso de vários recursos de edição de vídeo concomitantes, como imagem de fundo, caixas de textos, 
apresentação de outros filmes em janelas etc., optou-se por uma simplificação na construção dos vídeos educacionais, utilizando imagens de ótima resolução, sem efeitos, associadas à narração sincronizada. Pela sequencialidade e clareza na apresentação do conteúdo e levando-se em conta a carga cognitiva que poderá ser assimilada, espera-se contribuir para aumentar a eficiência da aprendizagem.

Segundo Timm et al. (2003), o uso adequado da linguagem de vídeo favorece o processamento cognitivo dos alunos em função do reconhecimento de padrões de visualização, de ritmo de apresentação e de narratividade que compõem o seu próprio repertório de representações. Ainda Timm et al. (2008) ressaltaram a importância de uma conveniente sinergia entre os estímulos visuais e auditivos e do uso de recursos, como cor, movimento e legendas de apoio, como mobilizadores da percepção e da atenção do aluno, para dar suporte à construção do conhecimento (Timm et al., 2008).

A decisão dos autores de utilizar a linguagem visual associada com o áudio vai ao encontro da pesquisa educacional que aponta a eficácia do uso de atividades multimídias e da importância de ofertar ao aluno formas diversificadas e redundantes do conteúdo (Mayer \& Gallini, 1990; Heyden, 2004; Stith, 2004; McClean et al., 2005). A diversificação da exposição do conteúdo fomenta o aprendizado-memória, impedindo a saturação dos mecanismos psicofisiológicos envolvidos no processamento de informações de mesma natureza, como demonstrado por De Almeida et al. (1995) e Thaddeu et al. (1997).

Através da organização gradual e esquemática das ilustrações e das animações, agregada à narrativa explicativa sucinta e aos recursos de repetição e pausa, acredita-se que os vídeos produzidos facilitem a aprendizagem dos conteúdos complexos da área morfológica.

As ilustrações e as animações também foram muito apropriadas na substituição das imagens de peças anatômicas humanas, não fornecidas pelo setor de Anatomia do departamento de Ciências Morfológicas. Assim, a dificuldade inicial com a ausência desse material resultou em uma concepção original de museu virtual de morfologia, onde o aspecto mórbido, característico dos ambientes virtuais de anatomia, foi substituído por um efeito visual lúdico, permitindo que esse ambiente de aprendizagem possa ser visitado inclusive por adolescentes e crianças.

Além do acervo permanente, que consiste nas seções Conhecendo a célula, Conhecendo o corpo humano e o Surgimento da vida, foi proposto um espaço virtual para exibição de trabalhos da área e de interesse clínico. Entretanto houve certa reserva dos colegas de departamento em colaborar com o projeto. Assim, o evento temático que era para ser temporário passou a ser fixo, e o tema escolhido foi Saúde da Mulher, exibindo apresentações elaboradas em Microsoft PowerPoint pelas monitoras da disciplina de Embriologia ou por orientadas de pesquisa.

Um contador de acesso permite acompanhar o número de visitantes.

Uma busca recente na Internet revelou que a proposta desse museu virtual continua inédita, já que são poucos os ambientes na área morfológica e eles geralmente se limitam a imagens de anatomia ou de histologia e não abordam a atividade funcional dos órgãos. Além disso, apresentam o conteúdo como atlas, sem os recursos digitais utilizados nesse trabalho. 
Espera-se que a elaboração desse ambiente de aprendizagem tenha contribuído para a difusão das Ciências Morfológicas, oportunizado o conhecimento do seu acervo ao visitante e, através dos vídeos e das animações, tenha propiciado de forma atraente a compreensão do desenvolvimento do indivíduo e dos constituintes do corpo humano.

\section{REFERÊNCIAS BIBLIOGRÁFICAS}

CABRAL JÚNIOR, P. A. F.; TIMM, M. I.; THADDEU, R. C. ; LEAL, M. B.; ZARO, M. A. Produção e validação de aula em vídeo como objeto de ensino para o curso de Medicina. RENOTE. Revista Novas Tecnologias na Educação, Porto Alegre, v.3, n.2, 2005.

COSTA, A. Compreender o Cinema. 2.ed. São Paulo: Globo, 1989.

DE ALMEIDA, R. M. M.; KESSLER, J. B.; THADDEU, R. C. A consolidação da memória humana, em labirinto circular, sofre interferência de tarefas em labirintos diferentes. In: REUNIÃO ANUAL DA FESBE, 10., 1995, Serra Negra. Anais. Serra Negra: Federação de Sociedades de Biologia Experimental, 1995.

HEYDEN, R. J. Approaches to Cell Biology: developing educational multimedia. Cell Biology Education, v.3, p.93-98, 2004.

MAYER, R. E.; GALLINI, J. K. When is an illustration worth ten thousand words? Journal of Educational Psychology, v.82, n.4, p.715-726, 1990.

McCLEAN, P.; JOHNSON, C.; ROGERS, R.; DANIELS, L.; REBER, J.; SLATOR, B. M.; TERPSTRA, J.; WHITE, A. Molecular and cellular Biology animations: development and impact on student learning. Cell Biology Education, v.4, p.169-179, 2005.

MONTANARI, T. Histologia: texto, atlas e roteiro de aulas práticas. 2.ed. Porto Alegre: UFRGS, 2012a. 178 p. Disponível em: < http://www.ufrgs.br/livrodehisto>

MONTANARI, T. Embriologia: texto, atlas e roteiro de aulas práticas. Porto Alegre: UFRGS, 2012b. 124 p. Disponível em: < http://www.ufrgs.br/livrodeembrio>

MONTANARI, T.; TIMM, M. I.; PERRY, G. T.; MOTTA, L. L.; BARILLI, S. L. S. Atlas de Biologia celular e tecidual. Porto Alegre: UFRGS, 2008. Disponível em: <www.ufrgs.br/atlasbiocel>

PIAGET, J. Psicologia e Pedagogia. 4.ed. Rio de Janeiro: Forense Universitária, 1976. $184 \mathrm{p}$.

PIAGET, J. Sobre Pedagogia. São Paulo: Casa do Psicólogo, 1998. 262 p.

SCHNAID, F.; ZARO, M. A.; TIMM, M. I. (org.). Ensino de Engenharia: do positivismo à construção das mudanças para o Século XXI. Porto Alegre: Ed. da UFRGS, 2006. 200 p.

SENGE, P.; CAMBRON-McCABE, N.; LUCAS, T.; SMITH, B.; DUTON, J.; KLEINER, A. Escolas que aprendem. Porto Alegre: Artmed, 2005. 336 p.

STITH, B. J. Use of animation in teaching Cell biology. Cell Biology Education, v.3, p.181-188, 2004.

THADDEU, R. C., KESSLER, J. B.; De ALMEIDA, R. M. M. Prejuízo da memória por interferências intercomportamentais - Dependência da natureza dos processos mentais mobilizados. In: CONGRESSO BRASILEIRO DE NEUROPSICOLOGIA, 3., 1997, São Paulo. Anais. São Paulo: Sociedade Brasileira de Neuropsicologia. 1997. 
TIMM, M. I.; BOS-MIKICH, A.; THADDEU, R. C.; CABRAL JÚNIOR, P. A. F.; AZEVEDO, A. M. P. Vídeos agregam valor ao trabalho do professor de ciências da saúde. RENOTE. Revista Novas Tecnologias na Educação, Porto Alegre, v.6, n.2, 2008.

TIMM, M. I.; SCHNAID, F.; ZARO, M. A., CABRAL JÚNIOR, P. A. F. Uso adequado de linguagem de vídeo para EAD. In: CONGRESSO INTERNACIONAL DE EDUCAÇÃ̃O A DISTÂNCIA, 10., 2003, Porto Alegre. Anais. Porto Alegre: Associação Brasileira de Educação a Distância, 2003. 